\title{
THE EFFECT OF PROBLEM BASED LEARNING AND TEAMS GAMES TOURNAMENTS MODEL TO IMPROVE COMPETENCIES
}

\author{
Eko Swi Damarwan ${ }^{1}$, Haryanto $^{2}$, La Tara ${ }^{3}$ \\ ${ }^{1,2}$ Department of Electrical Engineering Education, Universitas Negeri Yogyakarta, Indonesia \\ ${ }^{3}$ Department of Information Technology, National Technical Training Institute, Phnom Penh, Cambodia \\ E-mail: eko.swi2015@student.uny.ac.id
}

\begin{abstract}
This paper explores the potential of problem based learning and teams games tournaments model to improve students' competencies. The objective of the study was to know the differences in the achievement of basic electrical and electronic competencies of students in terms of cognitive and psychomotor aspects using problem based learning model, teams games tournaments, and conventional learning. This was a quasiexperimental study. Instrument validity was measured through expert judgments and instrument reliability with Spearman Brown. Data collection used a pretest, a posttest, and skill observations. Data analysis techniques used one way ANOVA and a Tukey's post hoc test with a significance level of 0.05 . The results revealed (1) differences in the achievement of basic electrical and electronic competencies of students in terms of cognitive and psychomotor aspects between using problem based learning, Teams Games Tournaments, and conventional learning, and (2) the results of the Tukey test showed the sequence of achievement of cognitive and psychomotor aspects of the best as follow: the model of teams games tournaments, problem based learning, and conventional learning.
\end{abstract}

Keywords: competence, problem based learning, teams games tournaments

\section{INTRODUCTION}

Vocational High School also known as Sekolah Menengah Kejuruan (SMK) is one of the formal educational institutions in Indonesia. SMK has expertise programs to suit the needs of the industrial world. SMK plays a role to produce graduates who are ready to work (Hanafi, 2014). Students of SMK must know the development of science and technology and able to compete in the industrial world. Based on the Regulation of the Indonesia Minister of Education and Culture No. 20 year 2016 about Graduate Competence Standards, it is explained that every graduate of a secondary education unit must have knowledge, attitude, and skill competencies. However, some SMK graduates do not have the competencies as expected. Competencies of SMK graduates are still low and less in line with the demand of the industrial world today, so many are unemployed. The number of unemployed from SMK graduates is the highest compared to Junior High School and Higher Education (Suryamin, 2015).
The learning activity in the classroom is one of the factors that affect student competence. Planning and learning process should be able to motivate students to participate actively. Learning planning based on the curriculum 2013 has some problems. Teachers have not been able to understand the curriculum being applied. Teachers are less innovative in planning learning activities, so students become bored and saturated.

The learning process in SMK is still teacher-centered. Teaching process is done by the teacher is still one direction that is from teacher to student. Based on the observation of electrical and electronic learning in SMK N 2 Yogyakarta, it is known that the learning process is still using the lecture method. Lecture methods including conventional learning models. Sulaiman (2004) suggests a conventional learning model is a teachercentered learning model. This model does not attract students' attention. Students tend to be passive in following learning activities. This has an impact on students' low understanding of the lesson. Basic electrical and electronic 
subjects are important productive subjects. Competencies given to this subject include unit material and electrical quantities, component introductions, resistor measurements, concepts and laws of electricity (Widiharso, 2013). These subjects should be taught interestingly. Competencies assessed in this study include the cognitive and psychomotor aspects.

The curriculum 2013 advocates the use of a scientific approach to the learning process. The scientific approach can be strengthened through the application of problem based learning models, research or discovery. Sanjaya (2011) explained that problem based learning (PBL) emphasizes the process of solving problems scientifically. Other researchers, Wastono (2015) found that the model of PBL can improve the independence and learning outcomes of vocational students. Students are given case studies to solve problems during the learning process. Implementation of problem based learning model, teachers have a role as a director and mentor. Students are given the opportunity to participate actively. Implementation of problem based learning model is based on scientific learning. The steps of implementing the problem based learning model according to Polya (2004) are (1) understanding the problems of explaining the objectives and learning materials by the teacher, (2) planning the problem solving, (3) implementing the problem-solving plan, and (4) reviews include analyzing and evaluating.

The implementation of the learning model in the curriculum 2013 requires a learning process that has contextual and cooperative characteristics. One of the cooperative learning models is Teams Games Tournaments (TGT) learning model. Slavin (2009) argues that Teams Games Tournaments' cooperative learning strategy is designed to rule out competition within the classroom that tends to lead to winning and losing parties. Veloo \& Chairhany (2013) declared cooperative learning type TGT create an active learning environment in completing exercises and discussions between students and teachers. This learning model involves students through games that include presentations, groups and tournaments/matches. In detail, Moore (2015) describes the Teams Games Tournament steps include (1) preliminary test, (2) determining student rankings, (3) dividing students into groups, (4) learning presentations, (5) provides student worksheets, (6) games, and (7) tournaments. The learning process is done in groups through games and tournaments. Such activities are expected to attract students to follow the learning process. In order for the teaching and learning process is directed and according to plan, the teacher acts as a moderator and designs class conditions in groups. Cooperative learning can improve student learning outcomes of SMK (Utami, 2015). By applying cooperative learning is expected to increase student participation in learning.

Learning process as mentioned above is also expected to make students interested and enjoy the given teaching materials. Implementation of the learning process is suggested based on the students. A fun learning and done with the use of game-based and tournaments-based learning models, inserted aims to develop the potential and diversity of children using child-centered principles (Suparman, 2015). Agree with that, Purnawan \& Sunarto (2015) argue that the model of learning TGT effective on student learning outcomes of SMK. It is intended that the learning objectives can be achieved optimally.

Based on the above description it can be interpreted that the competence of vocational students is still low, by using the model of PBL and TGT learning process done to be optimal. Thus the application of Curriculum 2013 supported by competence and adequate teacher resources are expected to improve student competence. Teachers with various efforts through the application of PBL and TGT models to realize learning processes that reflect a scientific, systematic, contextual, and collaborative approach. Learning model of PBL and TGT which is presented by the teacher and 
adapted to the material presented, it is expected that student learning outcomes can achieve the set goals.

\section{METHOD}

This study was categorized into experimental research. The type of experimental design used is a quasi-experiment. There are two types of groups in quasi experimental research that are control and experimental group. The control group was not treated, the experimental group 1 was treated using problem based learning, and the experimental group 2 was treated using Teams Games Tournaments. In the experimental group, the delivery of materials from teacher to student is assisted by interactive learning media of electrical engineering. The subjects were randomly selected. Selection of experimental group 1, experimental group 2, and control group is done by lottery, so that there are two experimental classes and one control class.

The research design used to know the cognitive and psychomotor aspects is the experimental design of three groups of pretestposttest control group design. Before the learning activity begins pretest in the control group and experimental group. At the end of the experiment is given a final test (posttest), the results are then compared. The design of cognitive aspects of research is in accordance with Table 1.

Table 1. Research Design

\begin{tabular}{lccc}
\hline \multicolumn{1}{c}{ Group } & Pretest & Treatment & Posttest \\
\hline Experiment 1 & $\mathrm{O}_{1}$ & $\mathrm{X}_{1}$ & $\mathrm{O}_{2}$ \\
Experiment 2 & $\mathrm{O}_{3}$ & $\mathrm{X}_{2}$ & $\mathrm{O}_{4}$ \\
Control & $\mathrm{O}_{5}$ & - & $\mathrm{O}_{6}$ \\
\hline
\end{tabular}

Where

O1: Pretest group using PBL model

O2: Posttest group using PBL model

O3: Pretest group using TGT model

O4: Posttest group using TGT model

O5: Pretest control group

O6: Posttest control group

X1: Treatment1 (Problem Based Learning)

X2: Treatment2 (Teams Games Tournaments)

The population of this study is the tenth grade students of expertise package Electric
Power Installation Technique (TITL) at SMK N 2 Yogyakarta. TITL's expertise package has 4 classes. The sample is determined by simple random sampling technique. The sample consists of 3 classes with 90 students. Class TITL1 was as experimental group 1, class TITL2 was as control group, and class TITL3 was as experimental group 2.

Methods of data collection to determine the cognitive abilities or knowledge of the students assessed through the instrument pretest and posttest. A pretest is done before the learning to know the level of knowledge and understanding of students about the basic materials of electronics, while posttest is done after completion of learning in one basic competence to know the level of student achievement after following the process of learning Basic Electricity and Electronics. Materials tested include basic competencies (1) describing and identifying electrical quantities based on international unit systems and (2) recognizing, reading, and measuring resistor values. There were 25 pretest and 25 posttest questions.

Data collection methods for measuring achievement level of psychomotor ability or Basic Electrical and Electronic student skills assessed through observation of student worksheet. Guidelines for the assessment of student worksheets are psychomotor levels that divide the psychomotor domain includes five levels. The sub-aspects assessed include: preparation, occupational health and safety, timeliness, implementation process, and report generation.

Validity test used in this study is the validity of the content and validity of the theory construction based on expert opinion (Expert Judgment). After consultation with the experts, the posttest and pretest instruments are tested on the students. The sample used for the test is different from the student to be subjected to research, but has the same characteristics. The test results were tested with empirical validity using the moment product formula from Pearson (Siregar, 2014). A total of 50 questions 
of pretest and posttest instruments were tested, 40 questions declared valid and the rest invalid. Reliability test in this study was using Spearman Brown formula. The calculation results obtained value 0.95 so that the instrument is declared reliable.

The first hypothesis in this study is:

$$
\begin{aligned}
& \mathrm{H}_{0}: \mu 1=\mu 2=\mu 3 \\
& \mathrm{H}_{\mathrm{a}}: \mu 1 \neq \mu 2 \neq \mu 3:
\end{aligned}
$$

Where

$\mathrm{H}_{0}$ : There is no significant difference in the achievement of basic electrical and electronic competencies of cognitive aspects, between conventional learning, PBL, and TGT.

$\mathrm{H}_{\mathrm{a}}$ : There are significant differences in the achievement of basic electrical and electronic competencies of cognitive aspects, between conventional learning, PBL, and TGT.

The second hypothesis in this study is:

$$
\begin{aligned}
& \mathrm{H}_{0}: \mu 1=\mu 2=\mu 3 \\
& \mathrm{H}_{\mathrm{a}}: \mu 1 \neq \mu 2 \neq \mu 3
\end{aligned}
$$

Where

$\mathrm{H}_{0}$ : There is no significant difference in the achievement of basic electric and electronics competencies of psychomotor aspects, between conventional learning, PBL, and TGT.
$\mathrm{H}_{\mathrm{a}}$ : There is a significant difference in the achievement of basic electrical and electronic competencies of psychomotor aspects between conventional learning, PBL, and TGT.

Data analysis techniques used one way ANOVA and Tukey's post hoc test with a significance level of 0.05 .

\section{RESULTS AND DISCUSSION}

The pretest data were obtained from all three classes received treatment. The pretest data consists of three parts, the pretest data of the class with the conventional learning, PBL, and TGT. The ideal minimum pretest value and the ideal maximum is 0 and 100 respectively. The pretest of the conventional learning class from 30 students used as research samples obtained the lowest, highest and mean values of $35.0,80.0$, and 62.67 respectively. The pretest result of the PBL class from 30 students who were taken as the research sample obtained the lowest, highest and mean values of 40,85 , and 61.33 respectively. The pretest result of TGT class from 30 students who were taken as the research sample obtained the lowest, highest and mean values of 40,85 , and 63.33 respectively. The pretest data can be seen in Table 2.

Table 2. Pretest Data

\begin{tabular}{lcccccc}
\hline \multicolumn{1}{c}{ Group } & Mean & Median & Modus & Value Min & Value Max & Standard Deviation \\
\hline Conventional & 62.67 & 65 & 70 & 35 & 80 & 11.72 \\
PBL & 61.33 & 62.5 & 70 & 40 & 85 & 12.03 \\
TGT & 63.33 & 65 & 65 & 40 & 85 & 10.69 \\
\hline
\end{tabular}

The posttest data were obtained after the three classes get treatments. Posttest data consists of three parts, namely posttest data of a conventional learning class, PBL and TGT. The ideal minimal posttest value is 0 and the ideal maximum value is 100 . The result of the conventional class posttest of 30 students taken as the research sample obtained the lowest, the highest and the mean values of $60.0,85.0$, and
72.17 respectively. Posttest results of PBL class from 30 students who were taken as research sample obtained the lowest, the highest and the mean values $65.0,95.0$, and 77.67 respectively. The results of the posttest of TGT class from 30 students who got the research sample obtained the lowest, the highest and the mean values 65 , 95, and 83 respectively. The posttest data summary is presented in Table 3 . 
Table 3. Posttest Data

\begin{tabular}{lcccccc}
\hline \multicolumn{1}{c}{ Group } & \multirow{2}{*}{ Mean } & \multirow{2}{*}{ Median } & Modus & $\begin{array}{c}\text { Value } \\
\text { Min }\end{array}$ & $\begin{array}{c}\text { Value } \\
\text { Max }\end{array}$ & $\begin{array}{c}\text { Standard } \\
\text { Deviation }\end{array}$ \\
\hline Conventional & 72.17 & 72.5 & 75 & 60 & 85 & 7.73 \\
PBL & 77.67 & 77.5 & 80 & 65 & 95 & 8.88 \\
TGT & 83 & 85 & 85 & 65 & 95 & 8.16 \\
\hline
\end{tabular}

Based on the ideal assessment, posttest data is classified into 4 categories of classes. In detail the classroom interval categories of posttest aspects are divided into very low, low, medium, and high. The calculation result of posttest value is then presented in figure diagram of frequency distribution. The bar chart image of the frequency distribution of posttest values is presented in Figure 1.

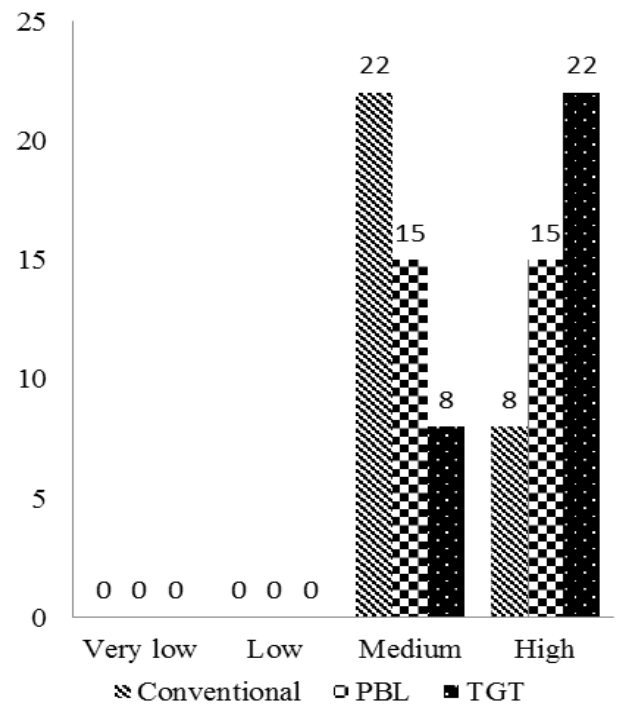

Figure 1. Frequency Distribution Chart of Student Posttest Values

Figure 1 shows that the value of posttest on conventional learning class there are 22 students or equal to $73.33 \%$ with a medium category and 8 students or $26.67 \%$ high category. The PBL model class is each of 15 students or $50 \%$ in medium and high category. Viewed from the TGT model class there are 8 students or $26.67 \%$ with medium category and 22 students or $73.33 \%$ high category. Posttest results show that the majority of students who use PBL and TGT are high category while for conventional learning is medium.

In terms of psychomotor aspects, the data consists of three parts, namely psychomotor data on conventional class, PBL, and TGT. The ideal minimum value that can be obtained on the psychomotor data that is equal to 20 and the ideal maximum value of 100 . The results of psychomotor observations of the conventional learning class of 30 students taken as research samples obtained the lowest, the highest and the mean values $70,82.5$, and 71.58 respectively. Psychomotor results of PBL class of 30 students who were taken as research samples obtained the lowest, the highest and the mean values of $60,87.5$, and 75.08 respectively. The psychomotor results of the TGT class of 30 students taken as the research samples obtained the lowest, the highest and the mean values of $70,87.5$, and 78.92 respectively. A summary of psychomotor data conventional class, PBL and TGT is presented in Table 4.

Table 4. Psychomotor Data

\begin{tabular}{lcccccc}
\multicolumn{1}{c}{ Group } & Mean & Median & Modus & Value Min & Value Max & $\begin{array}{c}\text { Standard } \\
\text { Deviation }\end{array}$ \\
\hline Conventional & 71.58 & 70 & 70 & 62.50 & 82.5 & 5.31 \\
PBL & 75.08 & 75 & 80 & 60 & 87.5 & 5.59 \\
TGT & 78.92 & 78.75 & 77.5 & 70 & 87.5 & 4.86 \\
\hline
\end{tabular}

Based on the ideal assessment, psychomotor data is classified into 4 categories of classes. In detail the classroom interval categories of psychomotor aspects are divided into very low, low, medium, and high. The calculation result of psychomotor value is then presented in figure diagram of frequency distribution. The bar chart image of the frequency distribution of psychomotor values is presented in Figure 2. 


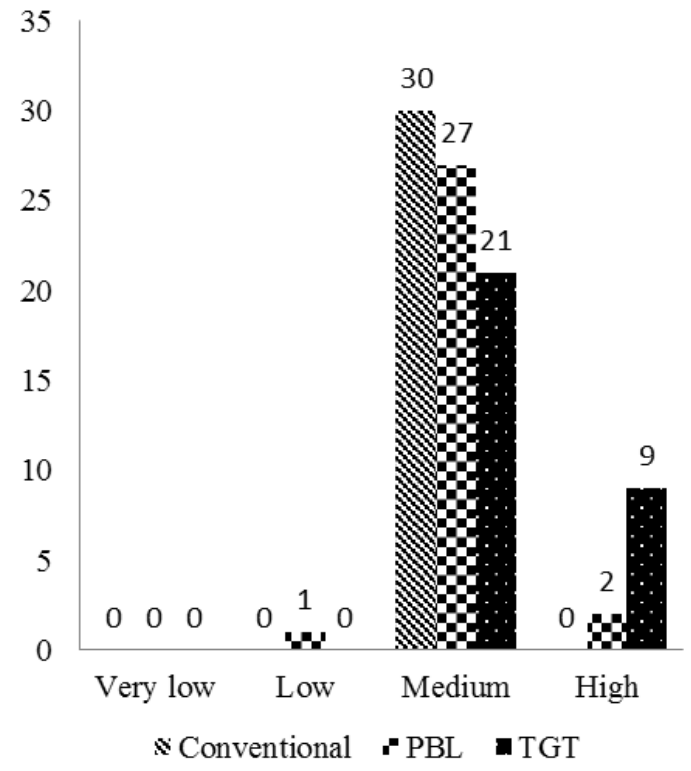

Figure 2. Frequency Distribution Chart of Student Psychomotor Value

Based on Figure 2 it can be explained that the psychomotor aspect value in the conventional learning class is 30 students or $100 \%$ in the medium category. In the PBL model class, the number of the students with psychomotor aspect values categorized as low, medium and high are 1 student or $3.33 \%, 27$ students or $90 \%$, and 2 students or $6.67 \%$ respectively. Viewed from the TGT model class there are 21 students or $70 \%$ in the medium category and 9 students or $10 \%$ high category. The majority of students using the PBL, TGT, conventional learning have medium categories on the psychomotor aspect.

The use of PBL models in basic electrical and electronic learning activities can make students have a great sense of curiosity. The PBL model encourages students to find problem solving. The PBL provides an opportunity for students to select and solve identified problems (Chapman and King, 2014). The learning process involves students and helps students think critically. The result of pretest and posttest value is used to know the students' competency improvement of cognitive aspect. Based on pretest and posttest values there is an increase in student competence seen in conventional learning class and PBL model class. The average bar chart drawings of the pretest and posttest results of the conventional learning and PBL are shown in Figure 3.

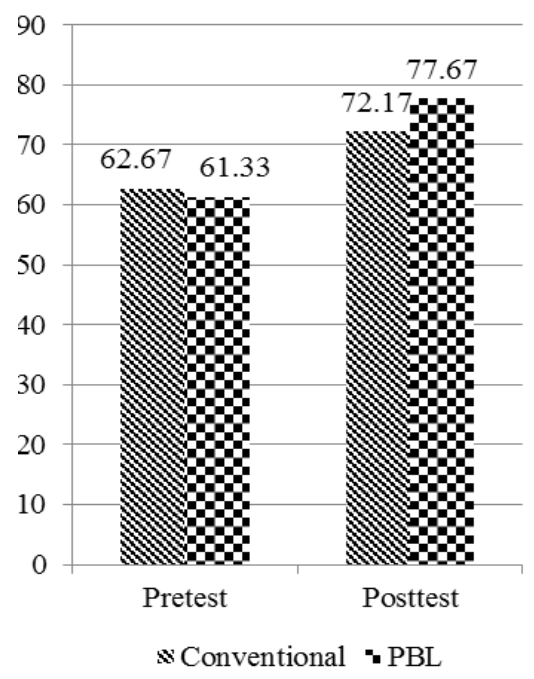

Figure 3. The Pretest and Posttest Results of the Conventional learning and PBL

Based on the average increase of data obtained can be explained that the increase in student competence cognitive aspects of the class PBL model is higher than the conventional learning class. Psychomotor aspect result is known that the mean of psychomotor value of learning in PBL model class is higher compared with the learning on conventional learning class that is 75.08 which is higher than 71.58 with difference of 3.5.

The TGT model is one of the cooperative learning models. Cooperative learning teaches students to work together in debates or discussions and specific group tasks. Cooperative learning involves understanding as a behavior to help among people in groups of two or more people. The success of work on the TGT model is strongly influenced by the involvement of each member of the group (Solihatin \& Raharjo, 2007).

Based on the result of pretest and posttest score, it is known that there is an improvement of students' competency in cognitive aspect, both in conventional learning class and TGT model class. The average bar chart drawings of the pretest and posttest results of the conventional learning and TGT are shown in Figure 4. 


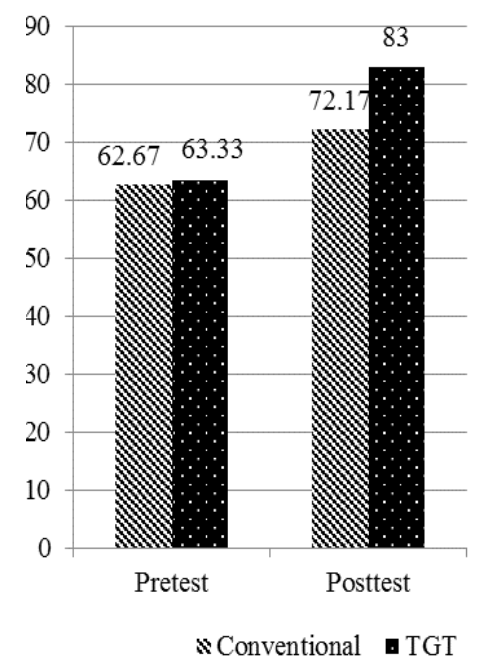

Figure 4. The Pretest and Posttest Results of the Conventional and TGT Model.

Based on the average increase of data obtained, it can be seen that the improvement of student competence cognitive aspects of the TGT model class is higher than the conventional learning class. Psychomotor aspect results obtained that mean of psychomotor value of learning in class of TGT model equal to 78.92 higher than learning at conventional learning class equal to 71.58 . The difference in mean psychomotor aspect is known to be 7.34

The next step is tested normality and homogeneity. Test normality and homogeneity of data from pretest, posttest, and psychomotor result of conventional class, PBL, and TGT, it is found that the distribution of data is normal and homogeneous distribution. Therefore, hypothesis testing can be continued by using parametric test statistics.

The hypothesis to be tested is to know the difference of learning achievement of cognitive aspect among students who follow the learning of conventional learning, PBL, and TGT. The first test conducted was testing the students' pretest data to see whether or not there was a significant difference in initial ability between conventional class students, PBL, and TGT. Test rule that if $F_{\text {count }}$ is less than $F_{\text {table, }}$, then $\mathrm{H} 0$ accepted. If $\mathrm{F}_{\text {count }}$ is higher than $\mathrm{F}_{\text {table, }}$ then $\mathrm{H} 0$ is rejected. The ANOVA summary of the pretest can be seen in the Table 5 .

Table 5. The ANOVA Summary of Student Pretest

\begin{tabular}{lllcccc}
\hline \multicolumn{1}{c}{ Group } & $\mathrm{N}$ & Mean & $\mathrm{F}_{\text {count }}$ & $\mathrm{F}_{\text {table (0.05)(2.87) }}$ & Sig. & Conclusion \\
\hline Conventional & 30 & 62.67 & & & & Ho \\
PBL & 30 & 61.33 & 2.35 & 3.15 & 0.791 & accepted \\
TGT & 30 & 63.33 & & & & \\
\hline
\end{tabular}

The conclusion of the data is that there is no significant difference in the pretest value of conventional class, PBL, and TGT, meaning that the initial ability between students is the same. The second test is the posttest test on the conventional class, PBL and TGT. This test is performed to determine whether or not there is a significant difference between posttest class of conventional learning, PBL, and TGT. The ANOVA summary of the posttest is in Table 6 .

Table 6. The ANOVA Summary of Student Posttest

\begin{tabular}{lllcccc}
\hline \multicolumn{1}{c}{ Group } & $\mathrm{N}$ & Mean & $\mathrm{F}_{\text {count }}$ & $\mathrm{F}_{\text {table }(0,05)(2,87)}$ & Sig. & Conclusion \\
\hline Conventional & 30 & 72.17 & & & & \\
PBL & 30 & 77.67 & 12.869 & 3.15 & 0.000 & Ho rejected \\
TGT & 30 & 83.00 & & & & \\
\hline
\end{tabular}

Based on Table 6 above, it is known $F_{\text {count }}$ of 12.869 is more than $F_{\text {table }}$ of 3.15 and a significance value of 0.000 is smaller than the significance level of 0.05 , then $\mathrm{H} 0$ is rejected. The conclusion of the data is that there is a significant difference between posttest value of conventional learning, PBL and TGT. The next stage is the advanced test. Further tests were conducted to find out further which groups had significant differences. Further tests were performed using Tukey's advanced computed assays. A summary of posttest cognitive aspects 
of conventional classes, PBL, and TGT is presented in Table 7 .

Table 7. The Tukey Post Hoc of Posttest

\begin{tabular}{llll}
\multicolumn{2}{c}{ Group } & Sig. & Conclusion \\
\hline Conventional & PBL & 0.031 & Significant \\
Conventional & TGT & 0.000 & Significant \\
PBL & TGT & 0.038 & Significant \\
\hline
\end{tabular}

Based on Table 7 it can be explained that student posttest results between conventional learning with PBL, conventional learning with TGT, and PBL model with TGT each have significant differences. This is evidenced by the significance value of Tukey's advanced test is smaller than 0.05 . The results of the Tukey test showed the sequence of achievement of cognitive aspects of the best as follow: the model of TGT, PBL, and conventional. The cognitive competence of students using PBL model is better than conventional learning because the PBL model gives students flexibility to solve their own problems. Students make plans and solve problems during learning activities.

Viewed from the TGT model, it is known that the cognitive competence of students is better than the PBL and conventional learning. This is because there are games and rewards on the TGT model. The presence of games and rewards make students more interested in learning activities.

The second hypothesis tested is the psychomotor test of conventional class, PBL and TGT. This test is conducted to determine whether or not there is a significant difference between the psychomotor aspects of conventional class, PBL, and TGT. A summary of the psychomotor aspect hypothesis test on conventional class, PBL, and TGT is presented in Table 8.

Table 8. The ANOVA Summary of Student Psychomotor

\begin{tabular}{llllccl}
\hline Group & $\mathrm{N}$ & Mean & $\mathrm{F}_{\text {count }}$ & $\mathrm{F}_{\text {table }(0.05)(2.87)}$ & Sig. & Conclusion \\
\hline Conventional & 30 & 71.58 & & & & \\
PBL & 30 & 75.08 & 14.582 & 3.15 & 0.000 & Ho rejected \\
TGT & 30 & 78.92 & & & & \\
\hline
\end{tabular}

The conclusion of this data is that there is a significant difference between psychomotor aspect value of conventional learning, PBL, and TGT. The next stage is the advanced test. Further tests were performed using Tukey's advanced computed assays. A summary of psychomotor aspects of conventional classes, PBL, and TGT is presented in Table 9.

Table 9. The Tukey Post Hoc of Psychomotor

\begin{tabular}{lccc}
\multicolumn{2}{c}{ Group } & Sig. & Conclusion \\
\hline Conventional & PBL & 0.031 & Significant \\
Conventional & TGT & 0.000 & Significant \\
PBL & TGT & 0.016 & Significant \\
\hline
\end{tabular}

Based on Table 9 it can be explained that student psychomotor results between conventional learning with PBL, conventional learning with TGT, and PBL model with TGT each have significant differences. This is evidenced by the significance value of Tukey's advanced test is smaller than 0.05 . The results of the Tukey test showed the sequence of achievement of psychomotor aspects of the best as follow: the model of Teams Games Tournaments, problem based learning, and conventional learning. The syntax of planning and problem solving makes the PBL model has better psychomotor aspects than conventional learning. This makes students more challenged to improve their psychomotor skills.

Seen from TGT model, it can be known psychomotor aspect of student is higher than at PBL and conventional learning. This is possible because of the syntax of games, matches and awards. Matches and awards make students more comfortable in following the learning activities. This is according to the results of the research of Erdogan and Senemoglu (2014) which PBL has a significant influence on student achievement in the level of knowledge, understanding, and higher levels. Similarly, the 
Jalani \& Sern (2014) study showed that student learning outcomes and skills on electrical circuit materials with PBL models are more effective than using conventional methods. The PBL model can further improve the basic electrical and electronic competence of students on the cognitive aspect.

In terms of TGT model, Purnawan \& Sunarto (2015) research result that cooperative learning method of TGT type is effective in terms of learning achievement and student's vocational learning satisfaction. Agreed with that, Frianto, Soetjipto, \& Amirudin (2016) explained that the application of TGT model can improve students' motivation and learning outcomes.

\section{CONCLUSION}

This study reveals the differences in the students' achievement of basic electrical and electronic competencies in terms of cognitive aspects of between students using problem based learning, teams games tournaments, and conventional learning. The results of the Tukey test showed the sequence of achievement of cognitive aspects of the best as follow the model of teams games tournaments, problem based learning, and conventional learning. There were differences in the students' achievement of basic electrical and electronic competencies in terms of psychomotor aspects between using problem based learning, teams games tournaments, and conventional learning. The results of the Tukey test showed the sequence of achievement of psychomotor aspects from the best are as follow: the model of teams games tournaments, problem based learning, and conventional learning. PBL and TGT models are effective for improving basic electrical and electronics competencies especially on the cognitive and psychomotor aspects. The cognitive and psychomotor competence of students using PBL model is better than conventional learning because the PBL model gives the students flexibility to solve their own problems. Students make plans and solve problems during learning activities. Viewed from the TGT model, it is known that the cognitive competence of students is better than the PBL and conventional learning. This is because there are games and rewards on the TGT model. The presence of games and rewards make students more interested in learning activities.

\section{REFERENCES}

Chapman, C., \& King, R. 2014. Planning and Organizing Standards - based Differentiated Instruction. ( $2^{\text {nd. }}$ ed.). USA: Corwin a SAGE Company

Erdogan, T., \& Senemoglu, N. 2014. Problembased Learning in Teacher Education: Its Promises and Challenges. Procedia Social and Behavioral Sciences 116, 459-463. Published by Elsevier

Frianto., Soetjipto, B. O., \& Amirudin, A. 2016. The Implementation of Cooperative Learning Model Team Game Tournament and Fan n Pick to Enhance Motivation and Social Studies Learning Outcomes. IOSR Journal of Humanities and Social Science (IOSR-JHSS). 21. 5, Ver. 7. 74-81

Hanafi, I. 2014. Pendidikan Teknik dan Vokasional. Yogyakarta: Deepublish

Jalani, N. H., \& Sern, L.C. 2014. Effects of Example-problem Based Learning on Transfer Performance in Circuit Theory. Journal of Technical Education and Training (JTET). 6.2, 28-38

Minister of Education and Culture. 2016. Permendikbud Nomor 20, Tahun 2016, tentang Standar Kompetensi Lulusan Pendidikan Dasar dan Menengah

Moore, K. D. 2015. Effective Instructional Strategies from Teory to Practice. $\left(4^{\text {th }}\right.$ ed.). Los Angeles: SAGE Publication USA 
Polya. G. 2004. How to Solve It: A New Aspect of Mathematical Method. Princeton and Oxford: Princeton University Press.

Purnawan \& Soenarto. 2015. Pengaruh Metode Kooperatif TGT dan NHT Terhadap Prestasi dan Kepuasan Pembelajaran Kelistrikan Otomotif di SMK. Jurnal Pendidikan Vokasi,. 5. 1, 27- 41.

Sanjaya, W. 2011. Perencanaan dan Desain Sistem Pembelajaran. Jakarta: Prenada Media Group

Siregar. S. 2014. Statistik Parametrik untuk Penelitian Kualitatif. Jakarta: Bumi Aksara

Slavin, R. E. 2009. Cooperative Learning; Teori, Riset, dan Praktik. (Penerjemah: Narulita Yusron). Bandung: Nusa Media.

Solihatin, E, \& Raharjo. 2007. Cooperative Learning; Analisis Model Pembelajaran IPS. Jakarta: Bumi Aksara.

Sulaiman, E. 2004. Pengenalan Pedagogi. Johor: University Teknologi Malaysia
Suparman. 2015. Terapkan Metode Pembelajaran Inovatif. Replubika (8 May 2015)

Suryamin. 2015. Pengangguran Terbanyak Lulusan SMK. Central Bureau of Statistics of Indonesia

Utami, S. 2015. Peningkatan Hasil Belajar Melalui Pembelajaran Kooperatif Tipe STAD pada Pembelajaran Dasar Sinyal Video. Jurnal Pendidikan Teknologi dan Kejuruan. 22. 4, 424-431

Veloo, A., \& Chirhany, S. 2013. Fostering Students' Attitudes and Achievement in Probability Using Teams-gamestournaments. Procedia Social and Behavioral Sciences.93, 59 - 64.

Wastono 2015. Peningkatan Kemandirian Belajar Siswa SMK pada Mata Diklat Teknologi Mekanik dengan Metode Problem Based Learning. Jurnal Pendidikan Teknologi dan Kejuruan, 22. 4, 398-400

Widiharso. 2013. Teknik Dasar Listrik Telekomunikasi. Ministry of Education and Culture of Indonesian. BSE 